Sains Malaysiana 50(10)(2021): 3127-3138

http://doi.org/10.17576/jsm-2021-5010-24

\title{
Impact of $\mathrm{Al}_{2} \mathrm{O}_{3}$ and $\mathrm{Dy}_{2} \mathrm{O}_{3}$ Substitution on the Physical, Structural and Radiation Shielding Properties of $\mathrm{Li}_{2} \mathrm{O}_{-} \mathrm{B}_{2} \mathrm{O}_{3}$ Glass System
}

(Kesan Penggantian $\mathrm{Al}_{2} \mathrm{O}_{3}$ dan $\mathrm{Dy}_{2} \mathrm{O}_{3}$ pada Sifat Fizikal, Struktur dan Pelindung Radiasi Sistem Kaca Li $\mathrm{O}_{2} \mathrm{~B}_{2} \mathrm{O}_{3}$ )

O.B. Aljewaw, M.K.A. Karim*, M.H.M. Zaid, M.K. Halimah, N.M. Noor, M.H.A. Mhareb \& Y.S. Alajerami

ABSTRACT

A new series of lithium-borate glass systems (23Li $\mathrm{O}_{2} 72 \mathrm{~B}_{2} \mathrm{O}_{3}$ in mol\%) were synthesized with the substitution of $\mathrm{Al}_{2} \mathrm{O}_{3}(5 \mathrm{~mol} . \%)$ as a modifier and doped with 0.3 and $0.5 \mathrm{~mol} \%$ of $\mathrm{Dy}_{2} \mathrm{O}_{3}$. Four series of glasses (S1, S2, S3 and S4) were synthesized via the conventional melt-quenching technique and characterized by using UV-Visible-NIR absorption spectrometer and Fourier transform infrared (FTIR) spectroscopy. The current investigation gives further insight on the structural and optical properties of the samples. The diffraction spectrum obtained from the X-ray Diffraction (XRD) analysis shows no typical peaks in the glass system, which indicates its amorphous phase. The optical properties of $\mathrm{Al}^{3+}$ and $\mathrm{Dy} \mathrm{y}^{3+}$ ions were evaluated and found that there is a pivot effect for the addition of $\mathrm{Al}_{2} \mathrm{O}_{3}$ and $\mathrm{Dy}_{2} \mathrm{O}_{3}$ for the glass system. Notably, the sample $S 2$ shows different behaviours for physical, structural, and optical properties compared with other prepared glass samples that can be attributed to the increment of $\mathrm{Al}_{2} \mathrm{O}_{3}$. Besides, the physical and ionizing shielding features were investigated for current glass samples. The radiation shielding properties were examined within the energy range of 0.015 until $15 \mathrm{MeV}$. The sample S4 has the optimum radiation shielding features as a result of the addition of $\mathrm{Dy}_{2} \mathrm{O}_{3}$. Hence, the composition attributes a new glass system that can be used in various applications such as radiation dosimeter and photon shielding materials.

Keywords: Dysprosium oxide; lithium-aluminium-borate glasses; radiation shielding properties; structural properties

ABSTRAK

Suatu siri baru sistem kaca litium-borat (23Li $\mathrm{O}_{2}-72 \mathrm{~B}_{2} \mathrm{O}_{3}$ dalam mol\%) disintesis dengan penggantian $\mathrm{Al}_{2} \mathrm{O}_{3}(5$ mol.\%) sebagai pengubah suai dan terdop dengan 0.3 dan 0.5 mol\% $\mathrm{Dy}_{2} \mathrm{O}_{3}$. Empat siri gelas (S1, S2, S3 dan S4) disintesis melalui teknik sepuh lindap konvensional dan dicirikan dengan menggunakan spektrometer penyerapan UV-boleh nampakNIR dan spektroskopi inframerah transformasi Fourier (FTIR). Kajian semasa memberikan gambaran lebih lanjut mengenai sifat struktur dan optik sampel. Spektrum belauan yang diperoleh dari analisis pembelauan sinar-X(XRD) tidak menunjukkan puncak khas dalam sistem kaca yang menunjukkan fasa amorfusnya. Sifat optik ion $\mathrm{Al}^{3+}$ dan $\mathrm{Dy}^{3+}$ dinilai dan didapati bahawa terdapat kesan pangsi pada penambahan $\mathrm{Al}_{2} \mathrm{O}_{3}$ dan $\mathrm{Dy}_{2} \mathrm{O}_{3}$ untuk sistem kaca. Terutama, sampel S2 menunjukkan tingkah laku yang berbeza untuk sifat fizikal, struktur dan optik berbanding dengan sampel kaca lain yang boleh dikaitkan dengan kenaikan $\mathrm{Al}_{2} \mathrm{O}_{3}$. Selain itu, ciri-ciri fizikal dan perlindungan mengion juga dikaji bagi setiap sampel kaca. Sifat pelindung diperiksa dalam julat tenaga dari 0.015 hingga $15 \mathrm{MeV}$. Sampel $S 4$ mempunyai ciri pelindung yang optimum disebabkan penambahan $\mathrm{Dy}_{2} \mathrm{O}_{3}$. Oleh itu, komposisi mengaitkan sistem kaca baru yang dapat digunakan dalam pelbagai aplikasi seperti dosimeter radiasi dan bahan pelindungan foton.

Kata kunci: Disprosium oksida; gelas litium-aluminium-borat; pencirian perlindungan sinaran; pencirian struktur

\section{INTRODUCTION}

Glass formers and modifiers for glass materials allows researchers to develop different types of glass systems as they can be used in many applications. These applications include radiation shielding, optical communication, solid-state laser, and radiation dosimeters (Gomaa et al. 2019; Hashim et al. 2015; Mhareb et al. 2014; Ramteke et.al 2014; Yasser Salleh et al. 2012). Generally, optical communication and radiation dosimeters rely on the chemical structure and nature of the glass matrix influence by the type of dopant, whereas radiation shielding materials depend on the addition of heavy metal oxide (HMO) as a modifier in glass formers (Alajerami et al. 2020; Mhareb 2020; Mostafa et al. 2017). 
Among the glass formers, borate glass is one of the most exciting materials due to its advantages, including its suitability as a solvent for rare-earth, lower melting point, better transparency and has higher thermal stability (Kumar et al. 2013). Borate glass has gain attention as reliable thermo-luminescence (TL) material because of its possible applications in photonic devices and in dosimetry for high energy physics including radiotherapy. Basically, borate glass comprised of $\mathrm{BO}_{3}$ triangular units and $\mathrm{BO}_{4}$ tetrahedral units and by adding alkaline oxides can enhance certain characteristics of borate glass (Khalilzadeh et al. 2016a). Lithium is a major alkali cation, and aluminium $\left(\mathrm{Al}_{2} \mathrm{O}_{3}\right)$ is a significant modifier (Mhareb et al. 2016). Besides, lithium is suitable for borate or any other glass formers as it increases the viscosity, reduces the melting point, and improves the physical properties.

The stability of the borate glass also relies on the lithium where the glass system forms the ionic bonds with oxygen and eventually reduces the hygroscopic nature of borate (Khalilzadeh et al. 2016b). The addition of $\mathrm{Al}_{2} \mathrm{O}_{3}$ ions to the glass matrix as modifiers improves the structural, magnetic, electrical, and optical conduct. During the forming of the borate-glass, the three trigonal oxygen's $\left(\mathrm{BO}_{3}\right)$ transforms into tetrahedrally coordinated oxygen's $\left(\mathrm{BO}_{4}\right)$, and this will be continued until $\mathrm{BO}_{3}$ and $\mathrm{BO}_{4}$ concentrations in the glass structure become balanced. Boron atoms are usually characterized in the glass by its high-strength covalent bonds $\mathrm{B}-\mathrm{O}$, and the modification depends on the ratio of $\mathrm{B}_{4}$ to $\mathrm{B}_{3}$, which in turn is affected by the concentration of the modifier oxides.

Glass system doped with $\mathrm{Dy}^{3+}$ also exhibited the good luminescence properties and sensitivity (Okasha et al. 2020). Since $\mathrm{Dy}^{3+}$ belongs to the lanthanide group, they are presented in the trivalent oxidation state (Mhareb et al. 2016). These trivalent lanthanide ions are known for their advantages in providing optical characteristics of $4 f$ electrons in lanthanide compounds. Lanthanide-doped glasses have been long-established as fundamental for driving applied research and commercialized production as they not only improve the spectroscopic characteristics but are also useful for laser applications (Mhareb et al. 2019a). The benefit of borate glasses over other glass forms has been shown in recent studies (Mhareb 2020; Yasser Salleh et al. 2013, 2012). These properties led to the utilization of borate glass in various fields such as laser, solar, radiation dosimeters, nonlinear, and other state-of-the-art technologies. However, there is limited discussion on doped lithium borate glasses with rare earth in radiation shielding. Hence, the main aim of this study was to evaluate the structural, physical, and optical properties of lithium-borate glass modified with alumina and doped with $\mathrm{Dy}^{3+}$.

\section{MATERIALS AND METHODS}

\section{MODEL AND DATA}

Four series of new glass samples were synthesized via the conventional melt-quenching technique. The substance of the glass prepared consists of a fine powder of lithium oxide, $\mathrm{Li}_{2} \mathrm{O}$ (99.5\%, Alfa Aesar), aluminum oxide, $\mathrm{Al}_{2} \mathrm{O}_{3}$ (99.995\%, Alfa Aesar), boron oxide, $\mathrm{B}_{2} \mathrm{O}_{3}$ (98\%, Acros Organics), and dysprosium oxide, $\mathrm{Dy}_{2} \mathrm{O}_{3}$ (99.9\%, Alfa Aesar). The present composition is tabulated in Table 1 and was prepared based on chemical equation: $23 \mathrm{Li}_{2} \mathrm{O}-(72-x)$ $\mathrm{B}_{2} \mathrm{O}_{3}-5 \mathrm{Al}_{2} \mathrm{O}_{3}$ with $-\mathrm{mol} \%$ of $\mathrm{Dy}^{3+}$ where $=0.3$ and 0.5 . The weight of each composition was obtained using an electronic balance and mixed accordingly in an agate mortar. Subsequently, the composition underwent a milling process for about $1 \mathrm{~h}$ at $90 \mathrm{rpm}$ to ensure the mixture was homogeneous. The powdered sample was poured in an alumina crucible and left in an electric furnace for $30 \mathrm{~min}$ at $1000{ }^{\circ} \mathrm{C}$ with a heating rate of $10^{\circ} \mathrm{C} / \mathrm{min}$, in atmospheric air. The melted mixture of the sample was immediately moved into a muffle furnace for another three hours at $400{ }^{\circ} \mathrm{C}$ for the annealing process. The annealing process helps to avoid the mechanical stress of the sample (Yasser et al. 2019).

TABLE 1. The raw materials with the concentration of each chemical for the composition of glass

\begin{tabular}{lllll}
\hline \multirow{2}{*}{ Samples } & \multicolumn{4}{c}{ Composition (mol.\%) } \\
\cline { 2 - 5 } & $\mathrm{Li}_{2} \mathrm{O}$ & $\mathrm{B}_{2} \mathrm{O}_{3}$ & $\mathrm{Al}_{2} \mathrm{O}_{3}$ & $\mathrm{Dy}_{2} \mathrm{O}_{3}$ \\
\hline $\mathrm{S} 1$ (LB) & 23 & 77 & -- & -- \\
$\mathrm{S} 2$ (LB: Al) & 23 & 72 & 5 & -- \\
S3 (LBA: Dy) & 23 & 71.7 & 5 & 0.3 \\
S4 (LBA: Dy) & 23 & 71.5 & 5 & 0.5 \\
\hline
\end{tabular}




\section{GLASS CHARACTERIZATION}

The amorphous phase of the samples was confirmed by an XRD analysis (PW 3040/60, Philips, Netherland) which was performed at angles of $2 \theta$ ranging from $10^{\circ}$ to $80^{\circ}$ by $(\lambda=1.54 \AA)$. The parameter for the test was set at $40 \mathrm{kV}$ and $30 \mathrm{~mA}$ at room temperature.

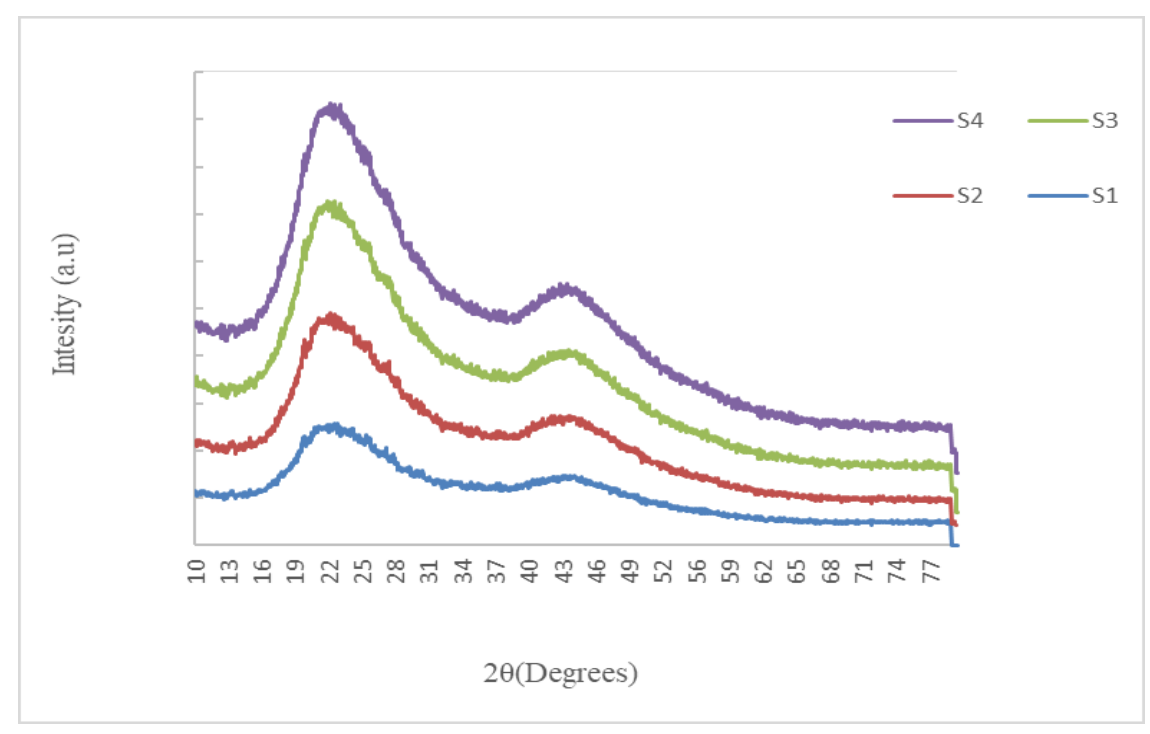

FIGURE 1. XRD pattern for $\mathrm{Li}_{2} \mathrm{O}-\mathrm{B}_{2} \mathrm{O}_{3}$ with $5 \% \mathrm{Al}_{2} \mathrm{O}_{3}$ as modifier and different concentrates doped $\mathrm{Dy}^{3+}$ ion

The density of the glass samples was calculated by using Archimedes' principle, where samples were immersed in the distilled water at room temperature.
Table 2 tabulates the density $(\boldsymbol{\rho})$ values, the physical and structural properties of each sample. Various equations were utilized to compute these properties, which can be obtained from the previous works (Kaur et al. 2019).

TABLE 2. Compositions and some physical properties of prepared glasses

\begin{tabular}{lllll}
\hline \multirow{2}{*}{ Physical properties } & \multicolumn{4}{c}{ Glass samples code } \\
\cline { 2 - 5 } & $\mathrm{S} 1$ & $\mathrm{~S} 2$ & $\mathrm{~S} 3$ & $\mathrm{~S} 4$ \\
\hline Density, $\rho(\mathrm{g} / \mathrm{cm} 3)$ & 2.076 & 2.082 & 2.146 & 2.167 \\
Average molecular weight, $\mathrm{M}(\mathrm{g})$ & 60.479 & 62.096 & 63.007 & 63.613 \\
Molar volume $\left(\mathrm{cm}^{3} / \mathrm{mol}\right)$ & 29.132 & 29.825 & 29.360 & 29.355 \\
Ion concentration $\left(\mathrm{N} \times 10^{21}\right.$ ion $\left./ \mathrm{cm}^{3}\right)$ & & - & 6.153 & 10.257 \\
Polaron radius, $\boldsymbol{r}_{\boldsymbol{p}} \times 10^{-8}$ & & - & 2.198 & 1.854 \\
Inter-nuclear distance, $\boldsymbol{r}_{\boldsymbol{i}} \times 10^{-8}$ & & - & 5.457 & 4.602 \\
Field strength, $\mathrm{F} \times 10^{17}\left(\mathrm{~cm}^{2}\right)$ & & - & 3.361 & 4.725 \\
Boron-Boron distance $<\mathrm{d}^{\mathrm{B}-\mathrm{B}}>\times 10^{-8}$ & 4.720 & 4.455 & 4.416 & 4.405 \\
volume of boron atoms per mole & & & & \\
$\quad\left(\boldsymbol{V}_{\boldsymbol{B}}^{\boldsymbol{m}}\right)$ & 63.332 & 53.260 & 51.873 & 51.501 \\
Oxygen molar volume $(\mathrm{OMV})$ & & & & \\
Oxygen packing density $(\mathrm{OPD})$ & 11.469 & 11.742 & 11.559 & 11.598 \\
Packing density $\left(\mathrm{V}_{\mathrm{t}}\right)$ & 87.186 & 85.161 & 86.511 & 86.218 \\
Poisson ratio $(\sigma)$ & 0.621 & 0.608 & 0.618 & 0.619 \\
\hline
\end{tabular}


The visible and near-ultraviolet regions of the samples were measured using UV-vis-NIR spectroscopy (Shimadzu, Japan). The spectrophotometry results were

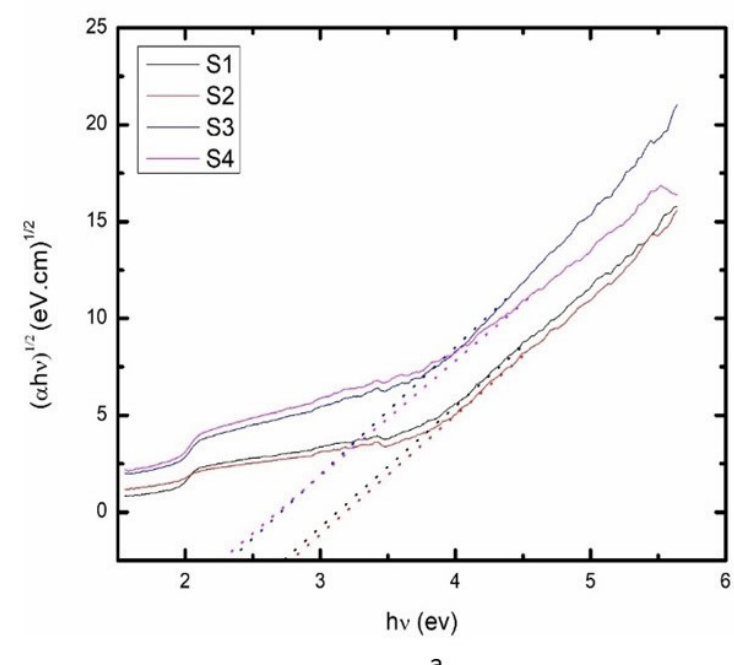

observed at the range 200 to $800 \mathrm{~nm}$ with a resolution around $0.1 \mathrm{~nm}$. The absorption peaks and band gap were obtained for each sample in Figure 2.

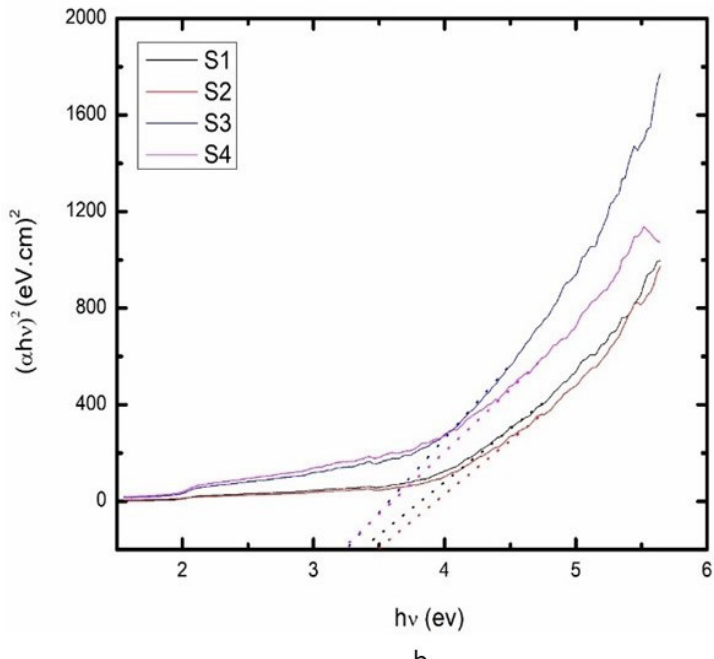

FIGURE 2. (a) Indirect, (b) direct of bandgap for $23 \mathrm{Li}_{2} \mathrm{O}-(72-\mathrm{x}) \mathrm{B}_{2} \mathrm{O}_{3}-5 \mathrm{Al}_{2} \mathrm{O}_{3}$ with $\mathrm{x}-\mathrm{mol} \%$ of $\mathrm{Dy}^{3+}$

The optical band gap energy was ascertained according to the absorption spectrum for the glass sample and the Mott and Davis formula (Mhareb et al. 2019a).
Other optical parameters were investigated for current glass samples and listed in Table 3 . Various equations were used for calculating the former parameters and can be found from the previous works (Yasser et al. 2013).

TABLE 3. Optical and energy properties of the prepared glasses

\begin{tabular}{lllll}
\hline \multirow{2}{*}{ Optical properties } & \multicolumn{3}{c}{ Glass samples code } \\
\cline { 2 - 5 } & $\mathrm{S} 1$ & $\mathrm{~S} 2$ & $\mathrm{~S} 3$ & $\mathrm{~S} 4$ \\
\hline Refractive index $(\mathrm{n})$ & 2.467 & 2.453 & 2.598 & 3.262 \\
Direct optical band gap $(\mathrm{eV})$ & 2.75 & 2.805 & 2.351 & 2.283 \\
Indirect optical band gap $(\mathrm{eV})$ & 3.49 & 3.405 & 3.258 & 3.231 \\
Dielectric constant $(\varepsilon)$ & 6.090 & 6.0178 & 6.751 & 6.885 \\
Reflection loss $(\mathrm{R})$ & 0.629 & 0.625 & 0.657 & 0.662 \\
Molar refractivity $\left(\mathrm{R}_{\mathrm{M}}\right)$ & 16.442 & 16.254 & 16.960 & 16.979 \\
Molar polarizability $\left(\alpha_{\mathrm{M}}\right) \times 10^{-24}$ & 6.521 & 6.446 & 6.726 & 6.734 \\
Optical dielectric constant & 5.090 & 5.017 & 5.751 & 5.885 \\
Optical electronegativity $(\chi)$ & 0.739 & 0.752 & 0.631 & 0.612 \\
Electron polarizability $\left(\alpha_{\mathrm{o}}\right)$ & 2.834 & 2.822 & 2.931 & 2.948 \\
Optical basicity $(\Lambda)$ & 1.330 & 1.323 & 1.384 & 1.393 \\
Metallization $(\mathrm{M})$ & 0.370 & 0.374 & 0.342 & 0.337 \\
Cutoff-wavelength $(\mathrm{nm})$ & 399 & 389 & 426 & 470 \\
\hline
\end{tabular}


The bonding of the functional groups in the glass was investigated by using the FTIR spectroscopy (Perkin Elmer, USA) in Figure 3. While the FTIR spectrum was acquired within a range of $400-4000 \mathrm{~cm}^{-1}$ and resolution of $0.85 \mathrm{~cm}^{-1}$ through thin pellet technique at a pressure of 77.2 MP. Each IR spectrum signifies the average of the measurement and normalized to the spectrum of the standardized pellets to optimize existing measurements and avoid any analysis errors.

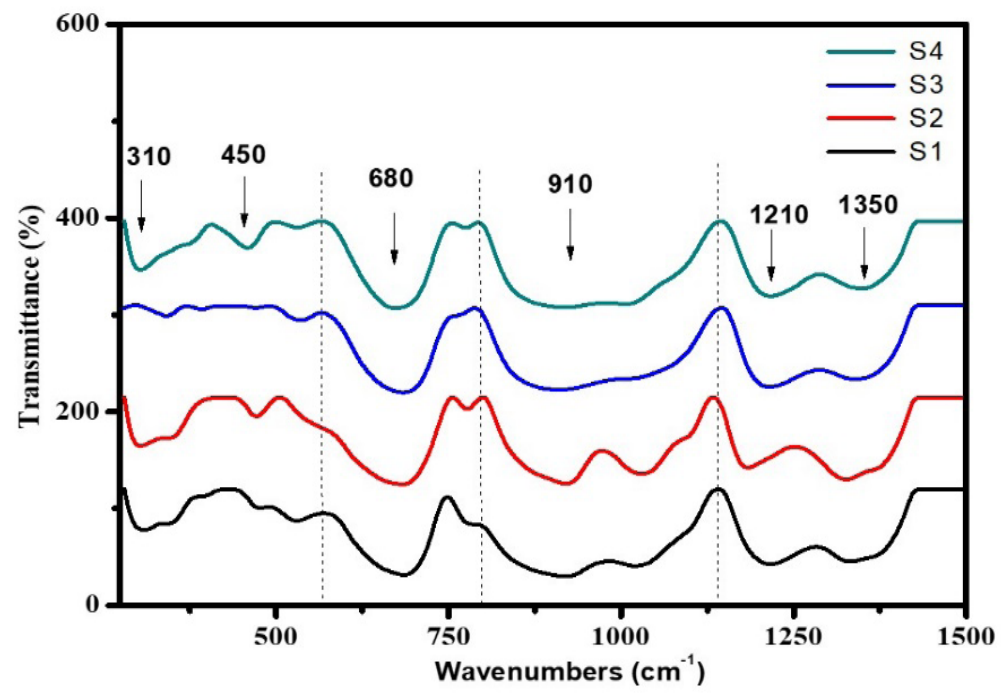

FIGURE 3. FTIR spectra of lithium alumina-borate glasses doped with $\mathrm{Dy}^{3+}$

The radiation shielding parameters were determined based on mass attenuation coefficient (MAC) values by using the Phy-X and XCOM programs. The calculated shielding properties included the half-value layer (HVL), effective atomic number $\left(\mathrm{Z}_{\text {eff }}\right)$, mean free path (MFP), effective electron density $\left(\mathrm{N}_{\text {eff }}\right)$, exposure build-up factor (EBF) and energy absorption build-up factor (EABF). All the formulas used for evaluating these parameters can be obtained from the previous works (Mhareb et al. 2019).

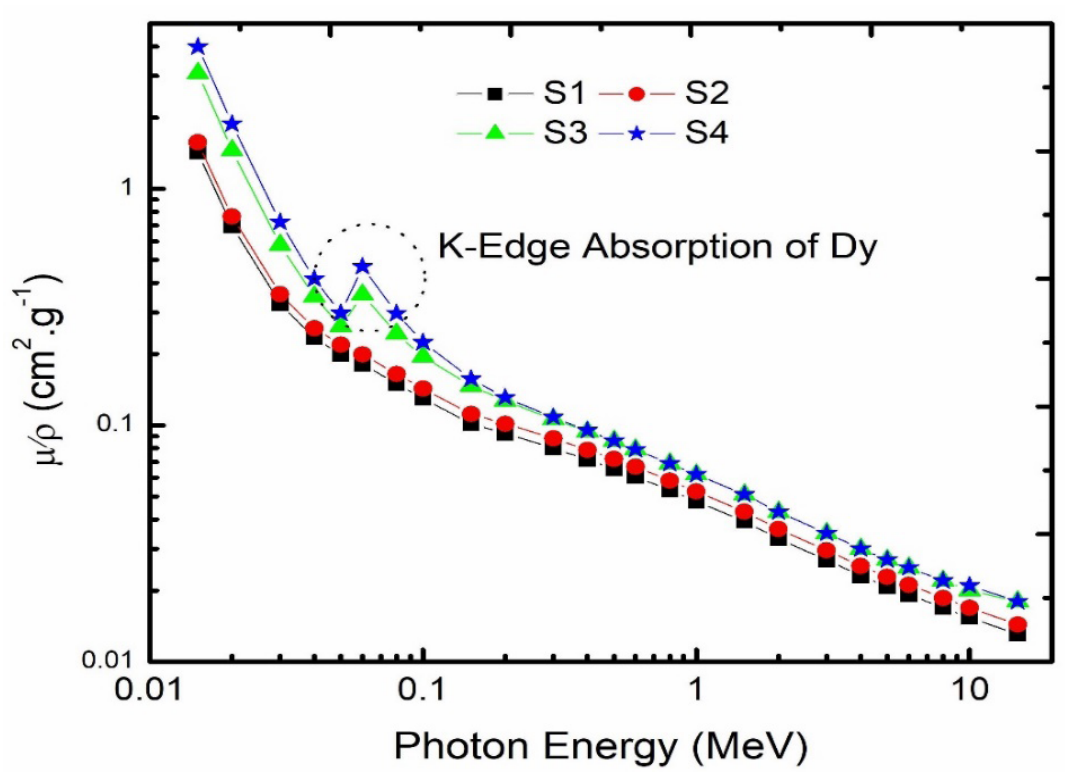

FIGURE 4. Variation of mass attenuation coefficient with photon energy for $\mathrm{S} 1-\mathrm{S} 4$ glass samples 


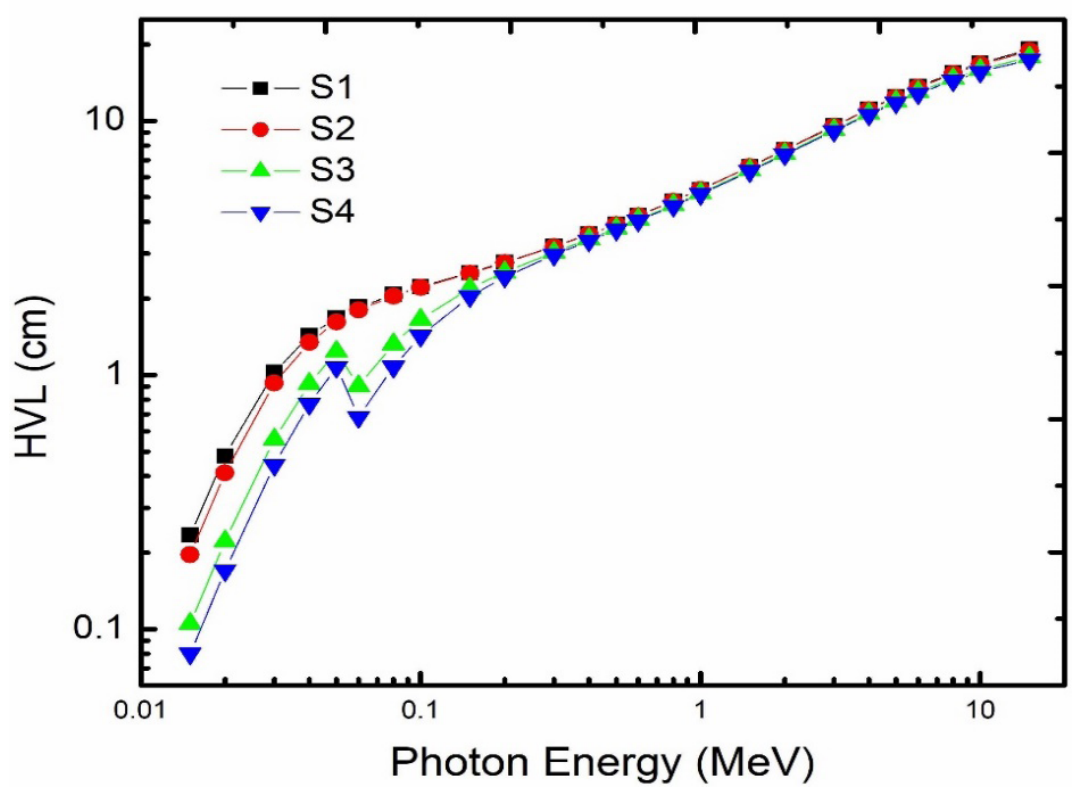

FIGURE 5. Variation of the Half Value Layer (HVL) with photon energy for new glass samples S1-S4

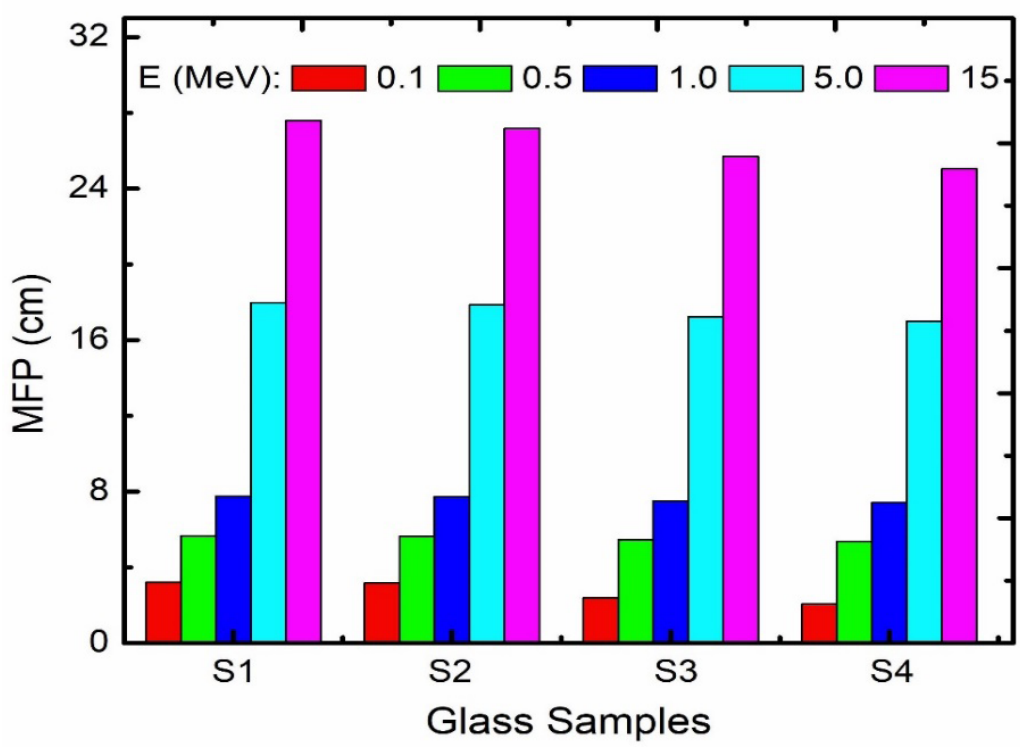

FIGURE 6. Variation of the mean free path with photon energy for the prepared glasses at different photon energies

\section{RESULTS AND DISCUSSION}

Figure 1 demonstrates the typical X-ray diffraction (XRD) pattern for all different glass concentrations. The XRD spectrum shows a broad hump with no presentation of a sharp peak, which affirmed the amorphous phase of the prepared glass samples. Notably, the density of the glass increases on account of the substitute of the light element (B) by heavier elements ( $\mathrm{Al}$ and Dy) as tabulated in Table 2. The increment in molar volume value for $\mathrm{S} 2$ with the addition of $\mathrm{Al}_{2} \mathrm{O}_{3}$ into the lithium borate (LB) is ascribed 

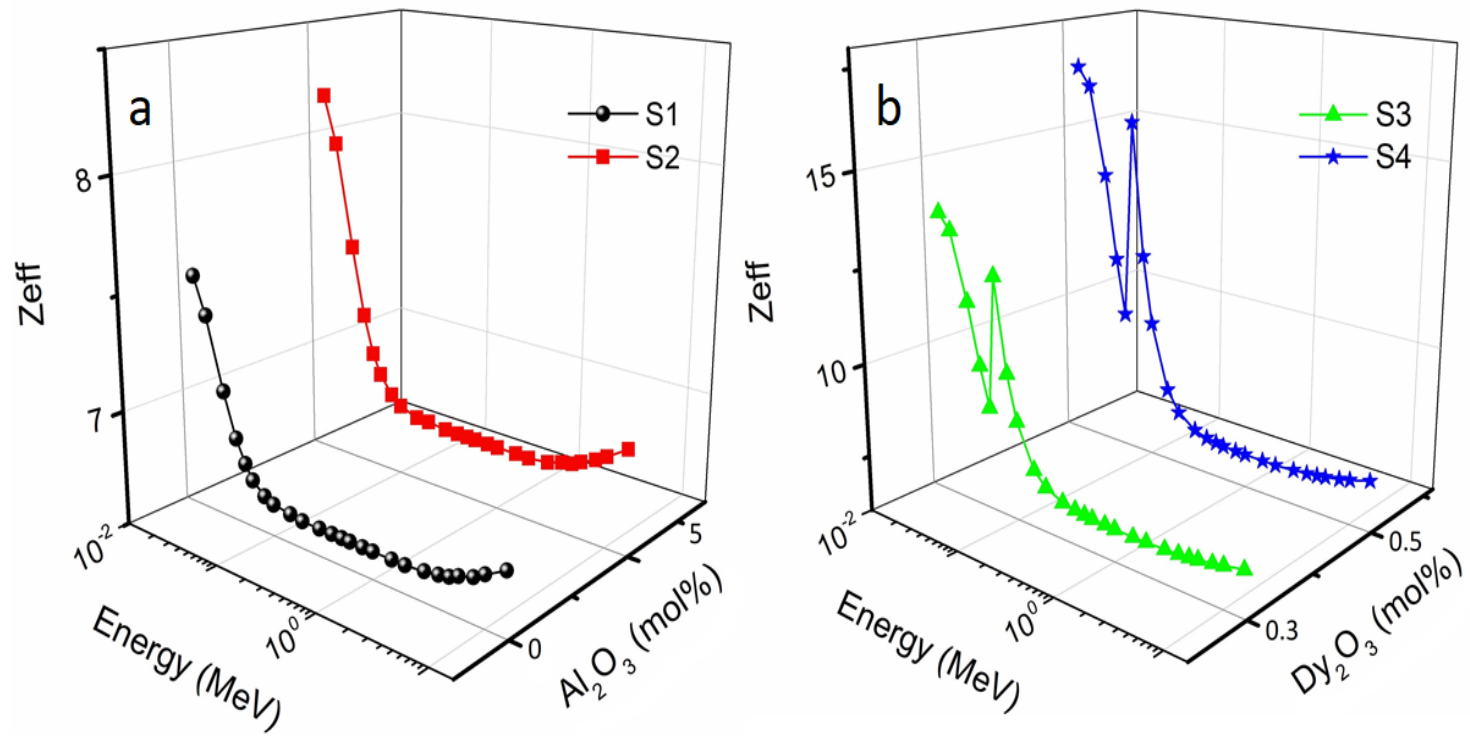

FIGURE 7. Effective atomic numbers of the prepared glasses at different energy levels

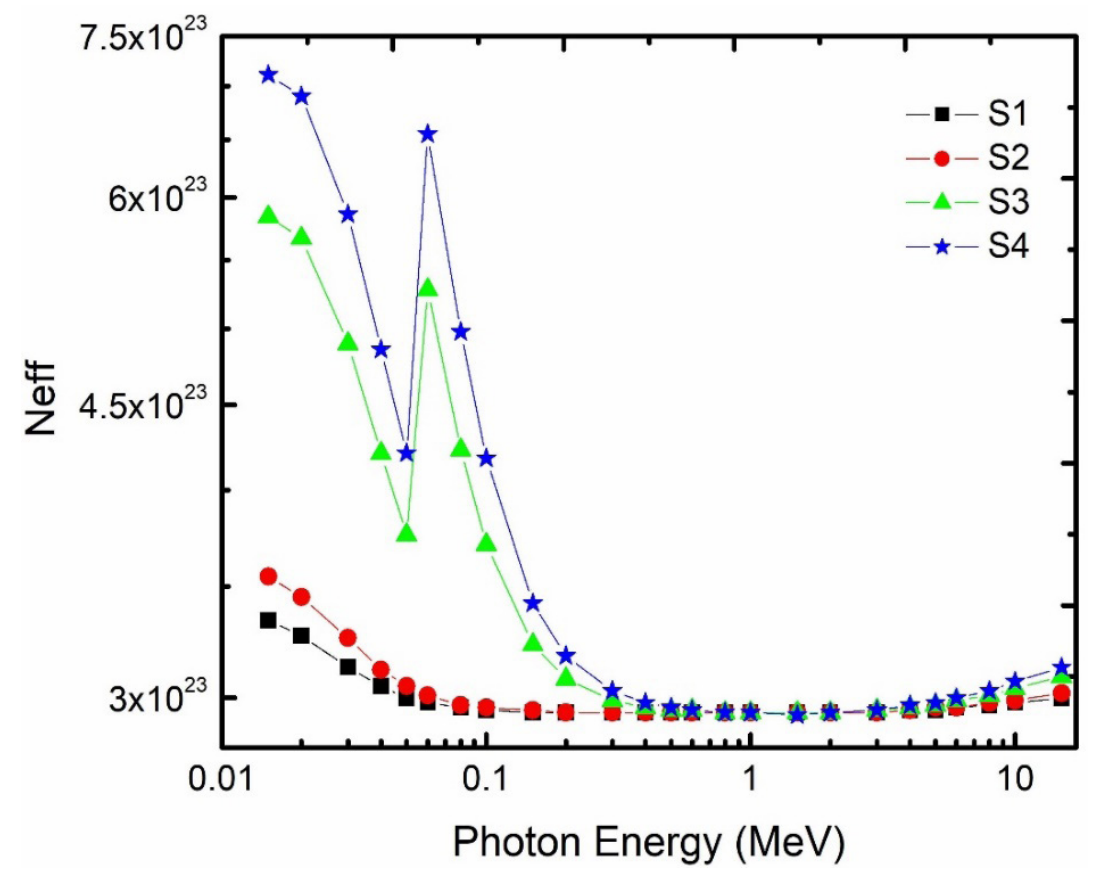

FIGURE 8.The effective electron density for the prepared glasses at different energy levels

to expand the glass system for $\mathrm{S} 2$, whereas the decrement in molar volume for S3 and S4 is linked to the compactness of the glass as a result of crowding the $\mathrm{Dy}_{2} \mathrm{O}_{3}$ in the glass system. The values of ion concentrations $(\mathrm{N})$ for samples S3 and S4 increase progressively. This increase is also due to the substantial number of mobile ions that 

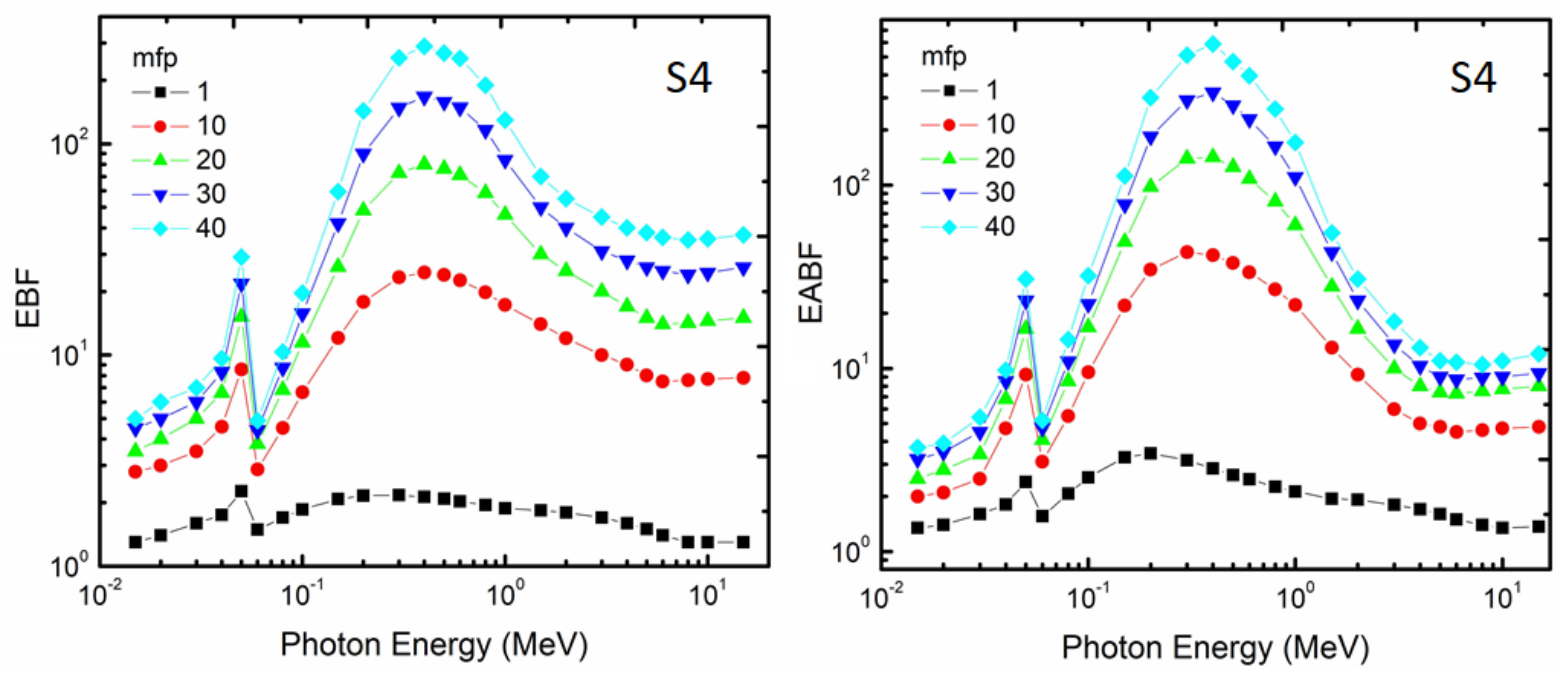

FIGURE 9. Variation of EBF and EABF values as a function of photon energies

suggest $\mathrm{Dy}^{3+}$ ions spread uniformly throughout the glass network (Mhareb et al. 2016). The polaron radius $\left(r_{p}\right)$ and Interatomic distance $\left(r_{i}\right)$ values exhibit a gradual decrement for the samples S3 and S4 that is due to the overfilling of $\mathrm{Dy}^{3+}$ ions inside the glass matrix. Hence, the glass system gains more abundant dysprosium interstices, which decreases the distance of average lanthanide-oxygen. As a result, the bond strength of Dy-O increases, creating a stronger field strength $(\mathrm{F})$ around the dysprosium ions for the samples S3 and S4 (Mhareb et al. 2016). Table 2 indicates the slight reduction in boron-boron distance values as a result of occurring stretching force for the bond in the glass system (Gedam \& Ramteke 2012). The volume of boron atoms per mole () values relies on the cation content in the glass system that is greatly associated with the ionic radius.

Atom packing can be evaluated by packing density $\left(V_{t}\right)$. As shown in Table 2, packing density for sample $\mathrm{S} 2$ has the lowest value compared with other samples that pointed to expand sample S2. The increment of the packing density values for $\mathrm{S} 3$ and $\mathrm{S} 4$ indicates compactness that is caused by overcrowding the $\mathrm{Dy}^{3+}$ in the glass matrix for these samples (Alajerami et al. 2019). The reduction in oxygen packing density (OPD) values and enhancement in oxygen molar volume (OMV) for sample $\mathrm{S} 2$ are attributed to increasing in non-bridging oxygen (NBO) with the addition of $\mathrm{Al}_{2} \mathrm{O}_{3}$ to the $\mathrm{LB}$ glass system that leads to the expansion in the glass matrix. The addition of $\mathrm{Dy}_{2} \mathrm{O}_{3}$ to the lithium aluminum borate (LAB) glass system led to enhancement in OPD and reduction of OMV as a result of creating bridging oxygen. Here, it can be noted that $\mathrm{Al}_{2} \mathrm{O}_{3}$ has a high ability to create $\mathrm{NBO}$ and expand the glass system for S2. Besides, Poisson's ratio $(\sigma)$ was calculated to estimate the rigidity for current samples; sample S2 has the highest rigidity as a result of increased linking in the glass matrix. Generally speaking, all samples have Poisson's ratio $(\sigma)$ values less than 0.3 , which indicates high cross-linking for all samples (Yasser Salleh et al. 2012).

Figure 2(a) and 2(b) illustrates the relationship between $(\alpha h v)^{1 / 2}$ and $(\alpha h v)^{2}$ and $h v$; this relationship represents the direct and indirect bandgap, respectively. Direct and indirect bandgap values have the same conduct. It has been noted that with the addition of $\mathrm{Al}_{2} \mathrm{O}_{3}$ to the LB may affect the values of direct and indirect bandgap increases. Afterward, the bandgap values show a reduction with the adding of the $\mathrm{Dy}_{2} \mathrm{O}_{3}$. The reduction in bandgap values is due to the change in the glass structure as a result of defects from the distribution of charge. Based on the defects created, the degree of localization increases then follows the increment in energy state for the oxygen ions nearer to the top of the valance band that leads to enhancing donor centers inside the glass structure. Table 3 shows that the lowest value for the refractive index was sample S2, and then the gradual increment occurs for refractive index values. This rise in refractive index values with the addition of $\mathrm{Dy}_{2} \mathrm{O}_{3}$ is related to an enhancement in the polarizability. The electrical properties of the prepared glass samples were evaluated by calculating many parameters such as dielectric constant $(\varepsilon)$ and optical dielectric constant (Gedam \& Ramteke 2012). The addition of $\mathrm{Dy}_{2} \mathrm{O}_{3}$ to lithium borate (LB) led to an incremental 
increase in dielectric constant $(\varepsilon)$ and optical dielectric constant that significantly increase the ion concentration in the glass sample.

In contrast, the addition of $\mathrm{Al}_{2} \mathrm{O}_{3}$ to $\mathrm{LB}$ reduces the dielectric constant $(\varepsilon)$ and optical dielectric constant. This result can be ascribed to the expansion of the glass structure caused by introducing $\mathrm{Al}_{2} \mathrm{O}_{3}$. The reduction of molar polarizability $\left(\alpha_{M}\right)$ and molar refractivity $\left(R_{M}\right)$ values with an addendum of $\mathrm{Al}_{2} \mathrm{O}_{3}$ to $\mathrm{LB}$ glass indicates that a modification of the glass structure has occurred. The optical electronegativity $(\chi)$ values show an inverse relationship with optical basicity $(\Lambda)$ and electron polarizability $\left(\alpha_{0}\right)$. The optical electronegativity $(\chi)$ value for S2 is higher than for other samples, and this result may be ascribed to expansion of the glass structure for sample S2 more than for other samples, while optical basicity $(\Lambda)$ and electron polarizability $\left(\alpha_{0}\right)$ for sample $\mathrm{S} 2$ are lower than for other samples, which can be related to the reduction covalent link between cation-oxygen. The reduction in metallization values points to narrower bandgap values, but it is noted that the $\mathrm{S} 2$ has the highest metallization value compared with other samples. This result conforms with bandgap results. Since the values of metallization were less than 1 , hence it may well-defined the non-metallic nature of the prepared glass samples. The cutoff-wavelength result of sample S2 appears to shift to the left side (less wavelength), which indicates an increase in the rigidity of S2 compared with other glass samples (Sayyed et al. 2019a). The obtained results fully agree with the Poisson ratio and physical properties results, and there is a strong relationship between the physical, structural and optical properties.

The FTIR spectrum in the mid-infrared (IR) region (400-1500 $\mathrm{cm}^{-1}$ ) for all glasses is shown in Figure 3 . The transmission spectrum observed shows that the prepared glass samples contain different vibrational bands and confirm structural unit $\mathrm{BO}_{4}$ formation, as shown in Figure 3. Each infrared spectrum showed several absorption bands localized around 400, 700, 900 and $1300 \mathrm{~cm}^{-1}$. A small band appears within the first phase, around $450 \mathrm{~cm}^{-1}$, which suggests that lithium oxide is in the compound. Moreover, the maximum intensity band centred at about $680 \mathrm{~cm}^{-1}$, showing that powerful banding of B-O-B structural network groups exists (Lakshminarayana et al. 2017a; Limkitjaroenporn et al. 2011). There is a slight change of the band at $910 \mathrm{~cm}^{-1}$, which suggests structural modifications and the formation of $\mathrm{BO}_{4}$ units (Raghda Saeif Eddin et al. 2014). Finally, the band area view at $1350 \mathrm{~cm}^{-1}$ explains the irregular stretching relaxation of the $\mathrm{B}-\mathrm{O}$ bond linked to trigonal
$\mathrm{BO}_{3}$ units.

The radiation shielding properties for current glass samples were investigated by different parameters with simulating the photon energy ranged from 0.015 till 15 $\mathrm{MeV}$. The first parameter is MAC, as depicted in Figure 4. The gradual enhancement in MAC values for the glass samples is obvious from Figure 4. Notably, the MAC values rely on the types of photon interactions with matter such as Compton scattering and the dominant contributors in MAC are photoelectric interactions. We note the reduction in MAC values with an increase in photon energy because the photoelectric interaction has an inverse relation with photon energy. The range of photon energy used in evaluation glass samples can be divided into three regions according to types of interactions. In the first region, the MAC values are highest. At 0.015 $\mathrm{MeV}, \mathrm{MAC}$ values are equal to 3.986, 3.082, 1.696, and $1.428 \mathrm{~cm}^{2} \mathrm{~g}^{-1}$ for $\mathrm{S} 4, \mathrm{~S} 3, \mathrm{~S} 2$, and $\mathrm{S} 1$. In the second region located between 0.15 and $1 \mathrm{MeV}$, the Compton scattering become more dominant. The third region placed for energy photon $>1 \mathrm{MeV}$. In this range, the pair production is more dominant to MAC values; therefore, the MAC values become constant with photon energy (Şakar, et al. 2020; Sayyed et al. 2019a). Also, the discontinuity at $53 \mathrm{keV}$ for S3 and S4 in Figure 4 can be attributed to K-edge for dysprosium element.

Figure 5 illustrates the HVL for synthesized glass samples. The figure presented the HVL value increase along with increases photon energy. The increment in HVL values was sharp at energy lower than $1 \mathrm{MeV}$, then it was followed by a gradual increment. The values of HVL at $0.015 \mathrm{MeV}$ for S1, S2, S3, and S4 are 0.234, $0.196,0.105$, and $0.080 \mathrm{~cm}$, respectively. It is worth mentioning that the HVL should increase with increments of photon energy, and this conduct can be seen in all types of materials, but the materials that have the lowest HVL are suitable to be employed as a shielding material especially for the gamma radiation. Another radiation shielding parameter, the Mean Free Path (MFP) was utilized to estimate the shielding features (Bagheri et al. 2017; Şakar et al. 2020). Figure 6 depicts the MFP for different energy $(0.1,0.5,1,5$, and $15 \mathrm{MeV})$. As shown in Figure 6, the MFP results are lowest at low energy for all samples. Sample S4 has the lowest MFP values due to the addition of $\mathrm{Dy}_{2} \mathrm{O}_{3}$ to the glass matrix.

The term $Z_{\text {eff }}$ is illustrated in Figure 7 and it shows the significant relation between the effective atomic number and photon energy. From Figure 7(a), the introduced $\mathrm{Al}_{2} \mathrm{O}_{3}$ to $\mathrm{LB}$ glass sample led to enhancement in $\mathrm{Z}_{\text {eff }}$ values. Where the addition of $\mathrm{Dy}_{2} \mathrm{O}_{3}$ to LAB 
appears further enhancement in $Z_{\text {eff }}$ results as exhibited in Figure 7(b), this enhancement is cause for replacement of (B) by (Al and Dy). The addition of $\mathrm{Dy}_{2} \mathrm{O}_{3}$ plays a pivotal role in the enhancement of $Z_{\text {eff }}$ at low energy that is ascribed to the occurrence of photoelectric interaction in this range. The reduction in $Z_{\text {eff }}$ with the increment in photon energy to intermediate range is a result of occurrence Compton interaction. Figure 8 exhibits $\mathrm{N}_{\text {eff }}$ for current glass samples. The $\mathrm{N}_{\text {eff }}$ has the same behavior for $Z_{\text {eff }}$ (Şakar et al. 2020).

The build-up factor for exposure (EBF) and the buildup factor for absorption (EABF) were determined by using the G-P fitting formulae (Kurudirek 2014; Mann \& Korkut 2013). Both EBF and EABF values were determined for S4 as a function of energy ranged from 1 till 49 MFP. As shown in Figure 9, three behaviours were reported: less than $0.1 \mathrm{MeV}, 1 \mathrm{MeV}$ and higher than $10 \mathrm{MeV}$. In the low energy, both EBF and EABF values are low, then started to increase gradually up to $0.05 \mathrm{MeV}$, followed by a sharp reduction at $0.06 \mathrm{MeV}$ due to the dysprosium K-edge photoelectric absorption. At intermediate energy (0.07 up to $1.5 \mathrm{MeV}$ ), the values of EBF and EABF increased with increasing the incident photon energy and reaching the maximum value of $0.4 \mathrm{MeV}$. At the high energy level $(>10 \mathrm{MeV})$, the EBF and EABF values decreased along with the increasing photon energy then increased after $4 \mathrm{MeV}$ (at this level probability of pair production increase). The current results was in line with the finding from previous related studies (Lakshminarayana et al. 2017a, 2017b).

\section{CONCLUSION}

Four series of borate glasses modified with aluminium oxides and lithium were synthesized via the melt-quench technique. Various concentrations of dysprosium oxides were added to the prepared glass as dopant and activator. It can be observed that there was an important modification in the optical, structural, and radiation shielding properties of the glasses. The addition of $\mathrm{Al}_{2} \mathrm{O}_{3}$ led to expanding the structure of glass, while the increment of $\mathrm{Dy}_{2} \mathrm{O}_{3}$ led to compacting the glass matrix. The gamma shielding properties were also investigated by calculating HVL, MFP, Zeff, Neff, EABF, and EBF. This outcome displayed the betterment in radiation shielding features with an addition of $\mathrm{Al}_{2} \mathrm{O}_{3}$ and $\mathrm{Dy}_{2} \mathrm{O}_{3}$ concentrations. The new glass samples show good results in shielding properties that can be proposed to be used as radiation shielding materials.

\section{ACKNOWLEDGEMENTS}

The authors are grateful to Biotechnology Research Center, Libya for scholarship study at Universiti Putra
Malaysia. The authors also wish to acknowledge support from Geran Putra of Universiti Putra Malaysia with the project number GP/IPM/UPM/9619800.

\section{REFERENCES}

Alajerami, Y.S., Drabold, D., Mhareb, M.H.A., Cimatu, K.L.A., Chen, G. \& Kurudirek, M. 2020. Radiation shielding properties of bismuth borate glasses doped with different concentrations of cadmium oxides. Ceramics International 46(8): 12718-12726. https://doi.org/10.1016/j. ceramint.2020.02.039.

Alajerami, Y.S.M., Mhareb, M.H.A., Abushab, K. \& Ramadan, K. 2019. Effect of co-doping of lithium on the dosimetric properties of dysprosium-doped sodium borate glass system. Physica B: Condensed Matter 558(February): 142-145. https://doi.org/10.1016/j.physb.2019.01.046.

Bagheri, R., Khorrami Moghaddam, A. \& Yousefnia, H. 2017. Gamma ray shielding study of barium-bismuth-borosilicate glasses as transparent shielding materials using MCNP-4C Code, XCOM program, and available experimental data. Nuclear Engineering and Technology 49(1): 216-223. https:// doi.org/10.1016/j.net.2016.08.013.

Gedam, R.S. \& Ramteke, D.D. 2012. Electrical and optical properties of lithium borate glasses doped with $\mathrm{Nd}_{2} \mathrm{O}_{3}$. Journal of Rare Earths 30(8): 785-789. https://doi. org/10.1016/S1002-0721(12)60130-6.

Gomaa, H.M., Sayyed, M.I., Tekin, H.O., Lakshminarayana, G. \& EL-Dosokey, A.H. 2019. Correlate the structural changes to gamma radiation shielding performance evaluation for some calcium bismuth-borate glasses containing $\mathrm{Nb}_{2} \mathrm{O}_{5}$. Physica B: Condensed Matter 567: 109-112. https://doi.org/10.1016/j. physb.2018.11.011.

Hashim, S., Mhareb, M.H.A., Ghoshal, S.K., Alajerami, Y.S.M., Bradley, D.A., Saripan, M.I., Tamchek, N. \& Alzimami, K. 2015. Luminescence characteristics of $\mathrm{Li}_{2} \mathrm{O}-\mathrm{MgO}-\mathrm{B} 2 \mathrm{O}_{3}$ doped with $\mathrm{Dy}^{3+}$ as a solid TL detector. Radiation Physics and Chemistry 116: 138-141. https://doi.org/10.1016/j. radphyschem.2015.04.007.

Kaur, P., Singh, K.J., Thakur, S., Singh, P. \& Bajwa, B.S. 2019. Investigation of bismuth borate glass system modified with barium for structural and gamma-ray shielding properties. Spectrochimica Acta - Part A: Molecular and Biomolecular Spectroscopy 206: 367-377. https://doi.org/10.1016/j. saa.2018.08.038.

Khalilzadeh, N., Bin Saion, E., Mirabolghasemi, H., Soltani, N., Bin Shaari, A.H., Bin Hashim, M., Mod Ali, N. \& Dehzangi, A. 2016a. Formation and characterization of ultrafine nanophosphors of lithium tetraborate $\left(\mathrm{Li}_{2} \mathrm{~B}_{4} \mathrm{O}_{7}\right)$ for personnel and medical dosimetry. Journal of Materials Research and Technology 5(3): 206-212. https://doi.org/10.1016/j. jmrt.2015.11.002.

Khalilzadeh, N., Saion, E. Bin, Mirabolghasemi, H., Shaari, A.H. Bin, Hashim, M. Bin, Ahmad, M.B.H., Mod Ali, N. \& Dehzangi, A. 2016b. Single step thermal treatment synthesis and characterization of lithium tetraborate nanophosphor. Journal of Materials Research and Technology 5(1): 37-44. https://doi.org/10.1016/j.jmrt.2015.05.005. 
Kumar, M.V.S., Rajesh, D., Balakrishna, A. \& Ratnakaram, Y.C. 2013. Optical absorption and photoluminescence properties of $\mathrm{Dy}^{3+}$ doped heavy metal borate glasses - Effect of modifier oxides. Journal of Molecular Structure 1041: 100-105. https://doi.org/10.1016/j.molstruc.2013.03.009

Kurudirek, M. 2014. Photon buildup factors in some dosimetric materials for heterogeneous radiation sources. Radiation and Environmental Biophysics 53: 175-185. https://doi. org/10.1007/s00411-013-0502-9.

Lakshminarayana, G., Baki, S.O., Kaky, K.M., Sayyed, M.I., Tekin, H.O., Lira, A., Kityk, I.V. \& Mahdi, M.A. 2017a. Investigation of structural, thermal properties and shielding parameters for multicomponent borate glasses for gamma and neutron radiation shielding applications. Journal of Non-Crystalline Solids 471: 222-237. https://doi. org/10.1016/j.jnoncrysol.2017.06.001.

Lakshminarayana, G., Baki, S.O., Lira, A., Sayyed, M.I., Kityk, I.V., Halimah, M.K. \& Mahdi, M.A. 2017b. X-ray photoelectron spectroscopy (XPS) and radiation shielding parameters investigations for zinc molybdenum borotellurite glasses containing different network modifiers. Journal of Materials Science 52: 7394-7414. https://doi.org/10.1007/ s10853-017-0974-0.

Limkitjaroenporn, P., Kaewkhao, J., Limsuwan, P. \& Chewpraditkul, W. 2011. Physical, optical, structural and gamma-ray shielding properties of lead sodium borate glasses. Journal of Physics and Chemistry of Solids 72(4): 245-251. https://doi.org/10.1016/j.jpcs.2011.01.007.

Mann, K.S. \& Korkut, T. 2013. Gamma-ray buildup factors study for deep penetration in some silicates. Annals of Nuclear Energy 51: 81-93. https://doi.org/10.1016/j. anucene.2012.08.024.

Mhareb, M.H.A. 2020. Physical, optical and shielding features of $\mathrm{Li}_{2} \mathrm{O}-\mathrm{B}_{2} \mathrm{O}_{3}-\mathrm{MgO}-\mathrm{Er}_{2} \mathrm{O}_{3}$ glasses co-doped of $\mathrm{Sm}_{2} \mathrm{O}_{3}$. Applied Physics A: Materials Science and Processing 126: 71. https:// doi.org/10.1007/s00339-019-3262-9.

Mhareb, M.H.A., Almessiere, M.A., Sayyed, M.I. \& Alajerami, Y.S.M. 2019. Physical, structural, optical and photons attenuation attributes of lithium-magnesium-borate glasses: Role of $\mathrm{Tm}_{2} \mathrm{O}_{3}$ doping. Optik 182: 821-831. https://doi. org/10.1016/j.ijleo.2019.01.111.

Mhareb, M.H.A., Hashim, S., Ghoshal, S.K., Alajerami, Y.S.M., Bqoor, M.J., Hamdan, A.I., Saleh, M.A. \& Abdul Karim, M.K.B. 2016. Effect of $\mathrm{Dy}_{2} \mathrm{O}_{3}$ impurities on the physical, optical and thermoluminescence properties of lithium borate glass. Journal of Luminescence 177: 366-372. https://doi. org/10.1016/j.jlumin.2016.05.002.

Mhareb, M.H.A., Hashim, S., Ghoshal, S.K., Alajerami, Y.S.M., Saleh, M.A., Dawaud, R.S. \& Azizan, S.A.B. 2014. Impact of $\mathrm{Nd}^{3+}$ ions on physical and optical properties of lithium magnesium borate glass. Optical Materials 37: 391-397. https://doi.org/10.1016/j.optmat.2014.06.033.

Mostafa, A.M.A., Issa, S.A.M. \& Sayyed, M.I. 2017. Gamma ray shielding properties of $\mathrm{PbO}-\mathrm{B}_{2} \mathrm{O}_{3}-\mathrm{P}_{2} \mathrm{O}_{5}$ doped with $\mathrm{WO}_{3}$. Journal of Alloys and Compounds 708: 294-300. https://doi. org/10.1016/j.jallcom.2017.02.303.
Okasha, A., Abdelghany, A.M. \& Marzouk, S.Y. 2020. The influence of $\mathrm{Ba}^{2+}$ and $\mathrm{Sr}^{2+}$ ions with the $\mathrm{Dy}^{3+}$ ions on the optical properties of lead borate glasses: Experimental and Judd-Ofelt comparative study. Journal of Materials Research and Technology 9(1): 59-66. https://doi.org/10.1016/j. jmrt.2019.10.029.

Raghda Saeif Eddin Said Dawaud, Suhairul Hashim, Yasser Saleh Mustafa Alajerami, Mhareb, M.H.A. \& Tamchek. N. 2014. Optical and structural properties of lithium sodium borate glasses doped $\mathrm{Dy}^{3+}$ ions. Journal of Molecular Structure 1075: 113-117. https://doi.org/10.1016/j. molstruc.2014.06.032.

Ramteke, D.D., Annapurna, K., Deshpande, V.K. \& Gedam, R.S. 2014. Effect of $\mathrm{Nd}^{3+}$ on spectroscopic properties of lithium borate glasses. Journal of Rare Earths 32(12): 1148-1153. https://doi.org/10.1016/S1002-0721(14)601964.

Şakar, E., Özpolat, Ö.F., Alım, B., Sayyed, M.I. \& Kurudirek, M. 2020. Phy-X/PSD: Development of a user friendly online software for calculation of parameters relevant to radiation shielding and dosimetry. Radiation Physics and Chemistry 166: 108496. https://doi.org/10.1016/j. radphyschem.2019.108496.

Sayyed, M.I., Kaky, K.M., Şakar, E., Akbaba, U., Taki, M.M. \& Agar, O. 2019. Gamma radiation shielding investigations for selected germanate glasses. Journal of Non-Crystalline Solids 512: 33-40. https://doi.org/10.1016/j. jnoncrysol.2019.02.014.

Sayyed, M.I., Mhareb, M.H.A., Abbas, Z.Y., Almousa, N., Laariedh, F., Kaky, K.M. \& Baki, S.O. 2019. Structural, optical, and shielding investigations of $\mathrm{TeO}_{2}-\mathrm{GeO}_{2}-\mathrm{ZnO}-$ $\mathrm{Li}_{2} \mathrm{O}-\mathrm{Bi}_{2} \mathrm{O}_{3}$ glass system for radiation protection applications. Applied Physics A: Materials Science and Processing. https:// doi.org/10.1007/s00339-019-2709-3.

Yasser Saleh Mustafa Alajerami, Suhairul Hashim, Ahmad Termizi Ramli, Muneer Aziz Saleh \& Taiman Kadni. 2013. Thermoluminescence characteristics of the $\mathrm{Li}_{2} \mathrm{CO}_{3}-$ $\mathrm{K}_{2} \mathrm{CO}_{3}-\mathrm{H}_{3} \mathrm{BO}_{3}$ glass system co-doped with $\mathrm{CuO}$ and $\mathrm{MgO}$. Journal of Luminescence 143: 1-4. https://doi.org/10.1016/j. jlumin.2013.04.023.

Yasser Saleh Mustafa Alajerami, Suhairul Hashim, Wan Muhamad Saridan Wan Hassan, Ahmad Termizi Ramli \& Azman Kasim. 2012. Optical properties of lithium magnesium borate glasses doped with $\mathrm{Dy}^{3+}$ and $\mathrm{Sm}^{3+}$ ions Physica B: Condensed Matter 407(13): 2398-2403. https:// doi.org/10.1016/j.physb.2012.03.033.

O.B. Aljewaw

Biotechnology Research Centre, Tripoli

P.O. Box Tajoura 3031

Libya

M.K.A. Karim*, M.H.M. Zaid, M.K. Halimah \& N.M. Noor Department of Physics, Faculty of Science

Universiti Putra Malaysia

43400 UPM Serdang, Selangor Darul Ehsan Malaysia 
M.H.A. Mhareb

Department of Physics, College of Science Imam Abdulrahman Bin Faisal University

P.O. Box 1982, 31441 Dammam

Saudi Arabia

M.H.A. Mhareb

Basic and Applied Scientific Research Center Imam Abdulrahman Bin Faisal University

P.O. Box 1982, 31441, Dammam

Saudi Arabia
Y.S. Alajerami

Physics and Astronomy, Science Faculty

Ohio University

USA

Y.S. Alajerami

Medical Imaging Department

Applied Medical Sciences Faculty

Al Azhar University-Gaza

*Corresponding author; email: mkhalis@upm.edu.my

Received: 9 October 2020

Accepted: 3 February 2021 